\title{
Fournier's gangrene: Review of 36 cases
}

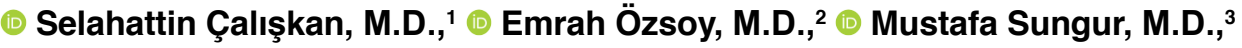 \\ (1) Hasan Tahsin Gözdaş, M.D. ${ }^{4}$
}

\begin{abstract}
1Department of Urology, Kanuni Sultan Süleyman Training and Research Hospital, İstanbul-Turkey
2Department of Urology, Haydarpaşa Numune Training and Research Hospital, İstanbul-Turkey

${ }^{3}$ Department of Urology, Hitit University Çorum Erol Olçok Training and Research Hospital, Çorum-Turkey

${ }^{4}$ Department of Infectious Disease and Clinical Microbiology, Abant İzet Baysal University Faculty of Medicire, Bolu-Turkey
\end{abstract}

\begin{abstract}
BACKGROUND: Fournier's gangrene (FG) is a very rare disease in daily urological practice. Despite medical improvements, mortality in FG is still high. Early diagnosis is very important to reduce additional instrumentations and mortality. In this study, we aimed to present the characteristics of the patients with Fournier's gangrene followed in two centers during ten years period.
\end{abstract}

METHODS: The medical records of patients with FG were reviewed retrospectively. The patient characteristics, causative pathogens, laboratory findings and treatment modalities were evaluated.

RESULTS: A total of 36 FG cases admitted between January 2008 and February 2018 were included in this study, consisting of 35 male patients, and one female patient with a mean age of $59.27 \pm 12.91$ years. The mean duration of hospital stay was $19 \pm 10.44$ days. The most common predisposing factor was diabetes mellitus, which was found in 28 patients. Malignancy was detected in three patients; prostate cancer in two patients and chronic lymphoblastic leukemia in one patient. Two patients had liver cirrhosis, and one patient had Behcet's disease and psoriasis. The microbiological agent was isolated from a wound culture in nine patients. After urgent surgical debridement, daily dressing with nitrofurazone (Furacin) was done. Additional debridement was conducted when necessary. Orchiectomy was performed in 10 patients; two of them underwent bilateral orchiectomy. One patient died because of sepsis on the seventh day of hospital admission.

CONCLUSION: FG is a life-threatening urological emergency with a high mortality rate. Treatment with broad-spectrum antibiotics and urgent surgery is pivotal for the prevention of mortality.

Keywords: Fournier's gangrene; morbidity; mortality; necrotizing fasciitis.

\section{INTRODUCTION}

Fournier's gangrene (FG) is a rare, life-threatening disease characterised by rapidly progressive necrotizing fasciitis of the perianal and genitourinary area and usually affects men. [1] The incidence was reported to be 1,6-3/100.000 with a 10/I male predominance. ${ }^{[2]}$ The disease was firstly reported by Baurienne in $1764 .^{[3]}$ He presented the case of a 45 -yearold man with scrotal gangrene and suggested radical surgical debridement of all the infected and necrotic tissues. After II 9 years, Jean-Alfred Fournier, a venereologist, reported five previously healthy young male with progressive gangrene of the penis and scrotum in 1883. ${ }^{[4]}$ Since this description of Fournier, the classical patient profile has been changed. ${ }^{[5]}$ Fournier's gangrene has been shown to be associated with several comorbidities and affects both genders, either young patients or elder ones as well.

There are some predisposing factors for FG, such as diabetes mellitus, alcoholism, atherosclerosis, peripheral arterial disease, trauma, tissue injury, malnutrition, immunosuppression, HIV infection, liver disease and leukemia. ${ }^{[6]}$ These predispos-

Cite this article as: Çalışkan S, Özsoy E, Sungur M, Gözdaş HT. Fournier’s gangrene: Review of 36 cases. Ulus Travma Acil Cerrahi Derg 2019;25:479-483.

Address for correspondence: Selahattin Çalışkan, M.D.

Kanuni Sultan Süleyman Eğitim ve Araştırma Hastanesi, Üroloji Kliniği, İstanbul, Turkey

Tel: +90 212 - 4041500 E-mail: dr.selahattin@gmail.com

Ulus Travma Acil Cerrahi Derg 2019;25(5):479-483 DOI: 10.14744/tjtes.2019.30232 Submitted: 10.10.2018 Accepted: 09.01.2019 Online: 20.08.2019

Copyright 2019 Turkish Association of Trauma and Emergency Surgery 
ing factors are related to poor prognosis and high mortality. Although the overall mortality rate is nearly $20-40 \%$, it can be as high as $\mathbf{7 0 - 8 0 \%}$ if the patient presents with sepsis.

This study aims to present the characteristics of 36 cases of FG followed in two medical centers during the ten years period.

\section{MATERIALS AND METHODS}

The patients who were diagnosed with FG and followed in two medical centers (Haydarpaşa Numune Training and Research Hospital and Çorum Erol Olçok Training and Research Hospital) between January 2008 and February 2018 were reviewed retrospectively. The patients who had missing data were excluded from this study. The clinical presentation, age, gender, surgical and medical treatments were recorded. The predisposing factors, hospitalization period and laboratory results were analyzed.

After starting broad-spectrum antibiotics, all patients underwent urgent surgery with wide debridement. The data were expressed as mean+standard deviation, median and percentage values using MedCalc statistical software demo version I7.6 (Ostend, Belgium, 2017).

\section{RESULTS}

There were 36 patients in the present study. Among these patients; 35 (97.2\%) were male, and one (2.8\%) was female. The mean age of the patients was $59.27 \pm 12.91$ years, and the hospitalization period was $19 \pm 10.44$ days. The diagnosis of FG was made by the characteristic clinical picture. The most common symptom was swelling (Fig. I). The most common predisposing factor was diabetes mellitus, which was found

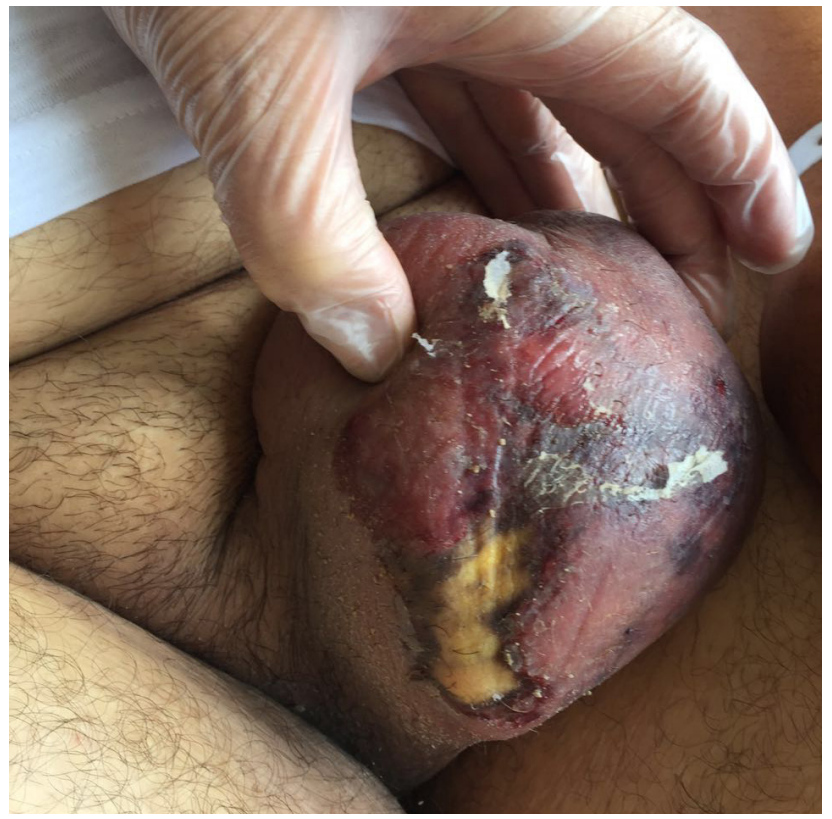

Figure 1. Scrotal oedema in a patient with Fournier's gangrene. in 28 patients. Malignancy was detected in three patients; prostate cancer in two patients and chronic lymphoblastic leukemia in one patient. Two patients had liver cirrhosis, and one patient had Behcet's disease and psoriasis. Table I shows the patient characteristics and predisposing factors.

Primary antimicrobial regimens were as follows: cefazolin+ gentamicin+metronidazole, ceftriaxone+metronidazole, imipenem, piperacillin/tazobactam+teicoplanin and meropenem+vancomycin. Antimicrobial treatment was revised according to culture antibiogram result of isolated microorganism. The microbiological agent was isolated from wound culture in nine patients: Escherichia coli in one patient, E.coli and Corynebacterium in two patients, E.coli and Candida albicans in two patients, Actinomyces turicensis in one patient, Bacteroides fragilis in one patient, methicillin-resistant Staphylococcus aureus in two patients. Laboratory results of the patients are summarized in Table 2.

After urgent surgical debridement, daily dressing with nitro-

Table I. Characteristics of the patients

\begin{tabular}{|c|c|c|c|}
\hline & \multicolumn{3}{|c|}{ Results } \\
\hline & $\mathbf{n}$ & $\%$ & Mean $\pm S D$ \\
\hline Number of the patients & 36 & 100 & \\
\hline Male & 35 & 97.2 & \\
\hline Female & 1 & 2.8 & \\
\hline Age (years) & & & $59.27 \pm|2.9|$ \\
\hline Hospital stay (days) & & & $19 \pm 10.44$ \\
\hline \multicolumn{4}{|l|}{ Clinical symptoms } \\
\hline Swelling & 21 & 58.33 & \\
\hline Erythema & 18 & 50 & \\
\hline Purulent collection & 16 & 44.4 & \\
\hline Pain & 14 & 38.9 & \\
\hline Fever & 5 & 13.9 & \\
\hline \multicolumn{4}{|l|}{ Comorbidities } \\
\hline Diabetes mellitus & 28 & 77.7 & \\
\hline Malignancy & 3 & 8.3 & \\
\hline Liver cirrhosis & 2 & 5.5 & \\
\hline Other & 2 & 5.5 & \\
\hline \multicolumn{4}{|l|}{ Additional surgery } \\
\hline Orchiectomy & 10 & 27.80 & \\
\hline Suprapubic tube placement & 3 & 8.33 & \\
\hline Mortality & 1 & 2.77 & \\
\hline Reconstruction & 31 & 100 & \\
\hline Primary closure & 21 & 67.75 & \\
\hline Flap techniques & 7 & 22.6 & \\
\hline Graft techniques & 3 & 9.67 & \\
\hline
\end{tabular}

SD: Standard deviation. 
Table 2. Laboratory test results of the patients

\begin{tabular}{|c|c|}
\hline Laboratory tests & Results \\
\hline White blood count $\left({ }^{*} 1000 / \mathrm{mm}^{3}\right)$, mean \pm SD & $16.69 \pm 5.54$ \\
\hline CRP (mg/dL), median (range) & $21.88(0.6-520)$ \\
\hline Hematocrit (\%), mean \pm SD & $37.29 \pm 8.48$ \\
\hline Leukocytosis $\left(>10.000 / \mathrm{mm}^{3}\right), \mathrm{n}(\%)$ & $34(94.4)$ \\
\hline Fever $\left(>38^{\circ} \mathrm{C}\right), \mathrm{n}(\%)$ & $5(13.9)$ \\
\hline Kidney injury $(\mathrm{Cr}>1.2 \mathrm{mg} / \mathrm{dL}) \mathrm{n}, \%$ & $13(36.11)$ \\
\hline Albumin (<4 g/dL), n (\%) & $32(96.96)$ \\
\hline \multicolumn{2}{|l|}{$\begin{array}{l}\text { Microbiological organism in } \\
\text { wound cultures, } n(\%)\end{array}$} \\
\hline Escheriscia coli (E.coli) & I (II.I) \\
\hline E.coli and Corynebacterium & $2(22.2)$ \\
\hline E.coli and Candida albicans & $2(22.2)$ \\
\hline Actinomyces turicensis & I (II.I) \\
\hline Bacteroides fragilis & I (II.I) \\
\hline Methicillin resistant Stafilococcus aureus & $2(22.2)$ \\
\hline
\end{tabular}

SD: Standard deviation.

furazone (Furacin) was done (Fig. 2). Additional debridement was conducted if necessary. Orchiectomy was performed in 10 patients; two of them underwent bilateral orchiectomy. One patient died because of sepsis on the seventh day of hospital admission.

\section{DISCUSSION}

Fournier's gangrene is one of the urological emergencies and characterized by progressive necrotizing fasciitis of the external genitalia and perineum. ${ }^{[7]}$ The annual incidence of this

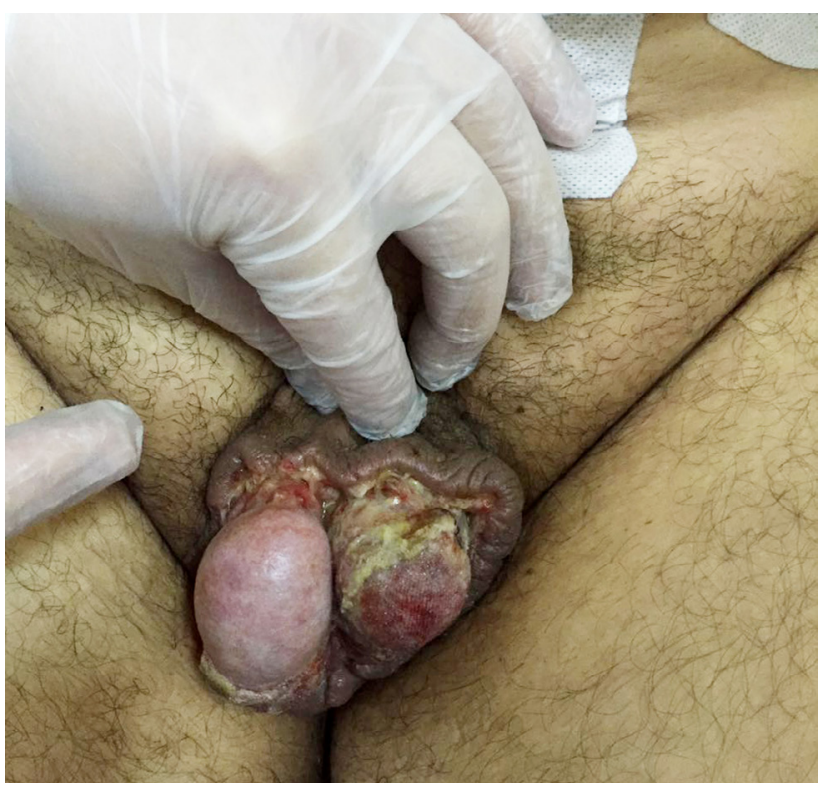

Figure 2. Dressing with nitrofurazone after urgent surgical debridement. disease is 1.6 per 100.000 in male patients, and the incidence increases with aging. Although pediatric cases are very rare, some pediatric cases have been reported from countries with limited sources in which poor hygiene is prevalent among immunocompromised children. ${ }^{[8]}$ The peak incidence is seen after 50 years of age. ${ }^{[7]}$ Fournier's gangrene is frequently diagnosed in males, but it may affect both genders in every age groups. ${ }^{\left[{ }^{9]}\right.}$ The reason for the lower prevalence in female patients can be explained by the simple drainage of the female perineum through the vaginal way. Another reason for the low prevalence in women is that most of the articles were reported by urology clinics, which led to males being overreported. The authors from urology clinics reported the rate of females as $0-5 \%$ in their studies. ${ }^{[5,10]}$ In contrast, studies from the other clinics reported that the female patients composed $56 \%$ and $28.8 \%$ of the whole patients..$^{[9,11]}$ In our study, the mean age of the patients was 59 years, and $97 \%$ of the patients were male.

The diagnosis of FG is usually made by physical examination. [9] The clinical presentation is variable depending on the infection stage, comorbidities and general health status of the patients. ${ }^{[12]}$ Tenderness, erythema, swelling and pain are the main symptoms. The patients can present with fever, malaise, local discomfort, purulent collection and sepsis. ${ }^{[13]}$ The differential diagnosis includes many diseases, such as cellulitis, acute epididymitis, orchitis, strangulated hernia, scrotal abscess, balanitis, herpes infection, pyoderma gangrenosum, polyarteritis nodosa, warfarin necrosis and ecthyma gangrenosum. ${ }^{[6]}$ Radiological examinations, such as X-rays, ultrasonography, computed tomography and magnetic resonance imaging techniques, may be helpful in the diagnosis when the diagnosis is uncertain. ${ }^{[12]}$ The ultrasonographic finding is thickened scrotal tissue due to inflammation and edema. Computed tomography is superior to radiography and ultrasonography, which shows soft tissue thickening, inflammation, abscesses and subcutaneous gas. Magnetic resonance imaging is expensive and time-consuming, which may cause a delay in the treatment. We diagnosed FG in our patients based on the characteristic clinical picture. We did not use radiological imaging. Most of the patients presented with swelling and erythema in this study.

Pathophysiologically, bacterial infection results in obliterating endarteritis, ischemia and eventually tissue necrosis. ${ }^{[13]}$ There are some predisposing factors, such as age, hypertension, chronic renal disease, obesity, hepatic diseases, alcoholism, congestive heart failure, peripheral vascular disease, smoking, immunosuppression, acquired human immunodeficiency syndrome, cachexia, diabetes mellitus and malnutrition. ${ }^{[2-14]}$ Some scoring systems were developed for the diagnosis and prognosis of FG. ${ }^{[12]}$ The Laboratory Risk Indicator for Necrotizing Fasciitis (LRINEC) scoring system includes age, gender, potassium, sodium, creatinine, platelet, C-reactive protein, leukocyte, hemoglobin and glucose. The Fournier Gangrene Severity Index (FGSI) predict the prognosis with some pa- 
rameters, including body temperature, heart rate, respiratory rate, sodium, potassium, creatinine, bicarbonate, leukocyte and hematocrit values.

FG is a polymicrobial infection of necrotizing soft tissues. ${ }^{[12]} E$. coli is the most common pathogen. Other bacterial pathogens are Streptococcus, Bacteroides, Enterobacter, Staphylococcus, Enterococcus, Corynebacterium, Klebsiella and Pseudomonas. This necrotizing soft tissue infection can be categorized into four groups based on the microbiological agent.

- Type I (polymicrobial) is the most common type and consists of more than $50 \%$ of the infections. There is synergistic action of aerobic, anaerobic and facultative anaerobic bacteria (E.coli, Pseudomonas and Bacteroides) and usually affects immunocompromised patients.

- Type 2 (monomicrobial) can be more aggressive than type I. Group A beta-hemolytic streptococcus is the most common agent.

- Type 3 is responsible for less than $5 \%$ of the infections and associated with Vibrio species or gram-negative bacteria. Crepitus because of the gas production is a common clinical finding.

- Type 4 (fungal) is due to Candida spp and Zygomycetes, which is usually seen in immunocompromised patients after trauma.

Effective resuscitation, broad-spectrum antibiotherapy and wide surgical debridement of necrotic tissues is the cornerstone of the treatment. ${ }^{[9]}$ Preoperative findings are lack of bleeding due to the thrombosis of the vessels, grey discoloration due to necrosis, edematous fluid and the absence of tissue resistance during dissection. ${ }^{[12]}$ All necrotic tissues must be debrided until the bleeding of the healthy tissues was detected. In our study, all of the patients underwent early surgical debridement after starting empiric antibiotherapy. There are some poor prognostic factors; delay in the treatment, primary anorectal disease, female gender, advanced age, diabetes mellitus, multiple organ failure and high FGSI scores. ${ }^{[9]}$ The mortality rate is still as high as $16-50 \%$ despite the modern diagnostic and treatment modalities.

There are some limitations to the current study. Firstly, this study includes a limited number of patients with a retrospective design. The lack of FGSI is the other limitation, and our study demonstrated data from only two medical centers that limit the results.
Fournier's gangrene is one of the rare urological diseases which has a high mortality rate. Early diagnosis and treatment with broad-spectrum antibiotics and surgical debridement are very important to decrease the mortality.

Conflict of interest: None declared.

\section{REFERENCES}

1. Althunayyan $\mathrm{S}, \mathrm{Karamitosos}$ E. Fournier's gangrene in an obese female in third trimester of pregnancy. Saudi Med J 2018;39:415-8. [CrossRef]

2. Taylor GM, Hess DV. Fournier gangrene: a rare case of necrotizing fasciitis of the entire right hemi-pelvis in a diabetic female. Oxf Med Case Reports 2018;2018:omx094. [CrossRef]

3. Baurienne H. Sur une plaie quisest terminee par la sphacele de la scrotum. J Med Chir Pharm 1764;20:251-6.

4. Fournier JA. Jean-Alfred Fournier 1832-1914. Gangrène foudroyante de la verge (overwhelming gangrene). Sem Med 1883. Dis Colon Rectum 1988;31:984-8. [CrossRef]

5. Ferretti M, Saji AA, Phillips J. Fournier's Gangrene: A Review and Outcome Comparison from 2009 to 2016. Adv Wound Care (New Rochelle) 2017;6:289-95. [CrossRef]

6. Kuzaka B, Wróblewska MM, Borkowski T, Kawecki D, Kuzaka P, Młynarczyk G, Radziszewski P. Fournier's Gangrene: Clinical Presentation of 13 Cases. Med Sci Monit 2018;24:548-55. [CrossRef]

7. Sorensen MD, Krieger JN, Rivara FP, Broghammer JA, Klein MB, Mack $\mathrm{CD}$, et al. Fournier's Gangrene: population based epidemiology and outcomes. J Urol 2009;181:2120-6. [CrossRef]

8. Bakshi C, Banavali S, Lokeshwar N, Prasad R, Advani S. Clustering of Fournier (male genital) gangrene cases in a pediatric cancer ward. Med Pediatr Oncol 2003;41:472-4. [CrossRef]

9. Yücel M, Özpek A, Başak F, Kılıç A, Ünal E, Yüksekdağ S, et al. Fournier's gangrene: A retrospective analysis of 25 patients. Ulus Travma Acil Cerrahi Derg 2017;23:400-4. [CrossRef]

10. Yanaral F, Balci C, Ozgor F, Simsek A, Onuk O, Aydin M, et al. Comparison of conventional dressings and vacuum-assisted closure in the wound therapy of Fournier's gangrene. Arch Ital Urol Androl 2017;89:208-11.

11. Chia L, Crum-Cianflone NF. Emergence of multi-drug resistant organisms (MDROs) causing Fournier's gangrene. J Infect 2018;76:38-43.

12. Voelzke BB, Hagedorn JC. Presentation and Diagnosis of Fournier Gangrene. Urology 2018;114:8-13. [CrossRef]

13. Dos-Santos DR, Roman ULT, Westphalen AP, Lovison K, Spencer Neto FAC. Profile of patients with Fournier's gangrene and their clinical evolution. [Article in English, Portuguese]. Rev Col Bras Cir 2018;45:e1430.

14. Hsu JM, Chen M, Weng CH, Tseng JS. Fournier's Gangrene: Clinical Characteristics in the Elderly. International Journal of Gerontology 2014;8:162-5. [CrossRef] 


\section{ORİIINAL ÇALIŞMA - ÖZET}

\section{Fournier gangreni: Otuz altı olgunun incelenmesi}

\section{Dr. Selahattin Çalışkan, ${ }^{1}$ Dr. Emrah Özsoy, ${ }^{2}$ Dr. Mustafa Sungur, ${ }^{3}$ Dr. Hasan Tahsin Gözdaş${ }^{4}$}

${ }^{1}$ Kanuni Sultan Süleyman Eğitim ve Araştırma Hastanesi, Üroloji Kliniği, İstanbul

${ }^{2}$ Haydarpaşa Numune Eğitim ve Araştırma Hastanesi, Üroloji Kliniği, İstanbul

${ }^{3}$ Hitit Üniversitesi Çorum Erol Olçok Eğitim ve Araştırma Hastanesi, Üroloji Kliniği, Çorum

${ }^{4}$ Abant Izzet Baysal Üniversitesi Tıp Fakültesi, Enfeksiyon Hastalıkları ve Klinik Mikrobiyoloji Anabilim Dalı, Bolu

AMAÇ: Fournier gangreni (FG) günlük üroloji pratiğinde çok nadir görülen bir hastalıktır. Tıbbi gelişmelere rağmen, FG'de mortalite hala yüksektir. İlave girişimlerin ve mortalitenin düşürülmesi için erken tanı çok önemlidir. Bu çalışmada, on yıl süresince iki merkezde izlenen FG'li hastaların özelliklerini sunmayı amaçladık.

GEREÇ VE YÖNTEM: Fournier gangrenli hastaların tıbbi kayıtları geriye dönük gözden geçirildi. Hastaların özellikleri, etken patojenler, laboratuvar bulguları ve tedavi yaklaşımları değerlendirildi.

BULGULAR: Ocak 2008-Şubat 2018 tarihleri arasında başvuran 35’i erkek ve biri kadın olmak üzere toplam 36 FG olgusu çalısmaya alındı. Hastaların yaş ortalaması $59.27 \pm 12.9 \mid$ idi. Hastanede kalıs süresi ortalama $19 \pm 10.44$ gündü. En sık predispozan faktör 28 hastada bulunan diyabetes mellitus idi. İki hastada prostat kanseri ve bir hastada kronik lenfoblastik lösemi olmak üzere üç hastada malignite saptandı. İki hastada karaciğer sirozu ve bir hastada da Behçet hastalı̆ıı ve sedef hastalığı vardı. Dokuz hastanın yara kültüründen mikrobiyolojik etken izole edilmiştir. Acil cerrahi debridman sonrası nitrofurazone (Furacin) ile günlük pansuman yapıldı. Gerektiğinde ilave debridman gerçekleştirildi. On hastaya orşiektomi uygulandı, bunlardan ikisi iki taraflı orşiektomi idi. Bir hasta hastaneye başvurusunun yedinci gününde sepsis nedeniyle kaybedildi.

TARTIŞMA: Fournier gangreni yüksek mortalite oranı ile hayatı tehdit edici bir ürolojik acildir. Geniş spektrumlu antibiyotikler ve acil cerrahi müdahale mortaliteyi önlemektedir.

Anahtar sözcükler: Fournier gangreni; morbidite; mortalite; nekrotizan fasiit.

Ulus Travma Acil Cerrahi Derg 2019;25(5):479-483 doi: 10.14744/tjtes.2019.30232 